\title{
DO IMPACTS OF FACTORS AFFECTING GOODS TRADE DIFFERENTIATE FOR SERVICE TRADE? THE CASE OF TURKEY ${ }^{1}$
}

\author{
Kafkas University \\ Economics and Administrative \\ Sciences Faculty \\ KAUJEASF \\ Article Submission Date: 22.04.2021 \\ Accepted Date: 23.09.2021 \\ Vol. 12, Issue 24, 202 \\ ISSN: $1309-4289$ \\ E - ISSN: 2149-9136
}

\section{Emre BİLGİÇ}

Res. Ass.

İzmir Bakırçay University

Faculty of Economics and

Administrative Sciences,

İzmir, Turkey

emre.bilgic@bakircay.edu.tr

ORCID ID: 0000-0003-1392-5320

\section{ABSTRACTI As known,}

international trade, which can be thought as the way that individuals, organizations, and countries fulfill their needs, is a very important concept. Although, for a long time, international trade has been associated with only international trade of physical products, especially after 2000 s, researchers have begun to think that there can be international trade of services which is different from international trade of goods. In this sense, both of differences among these two concepts, and factors, that possibly affect and are affected by these two concepts, became an area that requires to be understood clearly in the literature. Therefore, this research aims to analyze the relationship between the variables (globalization, foreign direct investment, informal economy, and internet technology), that are not widely studied in Turkish literature in terms of service trade, and Turkish service export. To understand the relationship among mentioned variables, cointegration analyzes was conducted for the period of 1970-2018 by using ARDL model. As a result of the analysis, it was understood that the answer to the question of whether the effects of the factors affecting the trade of goods differ for the export of services is yes based on the example of Turkey. In this direction, it has been observed that globalization has the opposite effect of what is expected. Lastly, this research provides some recommendations for policymakers.

Keywords: Service export, informal economy, globalization, foreign direct investment, internet technology

Jel codes: E26, F21, F14, F62

Scope: International Trade

Type: Research

DOI: 10.36543/kauiibfd.2021.043

Cite this Paper: Bilgiç, E. (2021). Do impacts of factors affecting goods trade differentiate for service trade? The case of Turkey. KAUJEASF, 12(24), 1056-1078.

${ }^{1}$ Compliance with the ethical rules of the relevant study has been declared. 


\section{MAL TICARETINI ETKILEYEN FAKTÖRLERIN ETKILERİ HIZMET IHHACATI İÇIN FARKLILAŞIYOR MU? TÜRKIYE ÖRNEĞİ}

\author{
Makale Gönderim Tarihi: 22.04.2021 \\ Emre BILGICC \\ Arş. Gör. \\ İzmir Bakırçay Üniversitesi \\ İktisadi ve İdari Bilimler Fakültesi, \\ İzmir, Türkiye \\ emre.bilgic@bakircay.edu.tr
}

ORCID ID: 0000-0003-1392-5320

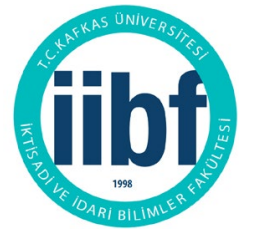

Kafkas Üniversitesi İktisadi ve İdari Bilimler Fakültesi$$
\text { KAÜIİBFD }
$$

Cilt, 12, Say1 24, 2021

ISSN: $1309-4289$

E - ISSN: 2149-9136

\section{ӦZ Bilindiği gibi bireylerin, örgütlerin}

ve ülkelerin ihtiyaçlarını karşılama şekli olarak düşünülebilecek olan uluslararası ticaret oldukça önemli bir kavramdır. Uzun bir süredir uluslararası ticaret sadece fiziksel ürünlerin uluslararası ticareti ile ilişkilendirilmesine rağmen özellikle 2000'lerden sonra araştırmacılar uluslararası hizmet ticaretinin uluslararası mal ticaretinden farklı olacağını düşünmeye başlamışlardır. Bu bağlamda hem bu iki kavram arasındaki farklılıklar hem de bu kavramları etkileyen ve bu kavramlardan etkilenen unsurlar literatürde anlaşılması gereken bir alan haline gelmiştir. Buradan hareketle bu çalışmada hizmet ihracatı kapsamında Türkçe literatürde çokça çalışılmayan değişkenler (küreselleşme, doğrudan yabancı yatırım, kayıt dışı ekonomi ve internet teknolojisi) ile Türk hizmet ihracatı arasındaki ilişkiyi analiz etmek amaçlanmıştır. Bahsi geçen ilişkileri anlamak için ARDL modeli kullanılarak 1970-2018 dönemi için eşbütünleşme analizleri gerçekleştirilmiştir. Yapılan analizler sonucunda Türkiye örneğinden hareketle mal ticaretini etkileyen faktörlerin etkileri hizmet ihracatı için farklılaşıyor mu sorusunun cevabının evet olduğu anlaşılmıştır. $\mathrm{Bu}$ doğrultuda küreselleşmenin beklenenin aksi yönde etki doğurduğu gözlemlenmiştir. Ayrıca bu çalışma politika yapıcılar için tavsiyelerde de bulunmaktadır.

Anahtar Kelimeler: Hizmet ihracatı, kayıt dışı ekonomi, küreselleşme, doğrudan yabanc yatırımı, internet teknolojisi

JEL Kodu: E26, F21, F14, F62

Alan: Uluslararast Ticaret

Türü: Araştırma 


\section{INTRODUCTION}

As known, trade is a very ancient term in which its history dates to prehistoric times. Trade, which can be simply defined as an exchange of goods and/or services among people, is one of essential daily life activities in human life. Individuals, organizations, and governments must engage in trade activities to sustain their activities because the way, that they can fulfill their needs, is trade. Therefore, they always pursue trade activities in their routines. From prehistoric times to the present, volume and scope of trade have enlarged incredibly especially with the fastened globalization process. Since this situation has made trade more significant for all elements of the society, trade (particularly international trade) has become one of widely examined research areas throughout the last two centuries.

For a long time, international trade has been associated with only international trade of physical products. However, especially after 2000s, researchers have begun to think that there can be international trade of services which is different from international trade of goods in terms of the process that trade activities realized, the volume of them, buyer-seller relationships etc. So that, they have started to conduct research which mainly focus on differences between international trade of goods and international trade of services (Lennon, 2008; Ariu, 2016). In this sense, they have found out differences between international trade in goods and international trade in services such as differences in impact of language and physical geography on them and the amount of export and import of goods and services (Lennon, 2008; Ariu, 2016).

Since international trade in goods and international trade in services are thought as separate concepts from each other, researchers have thought that factors that was considered as influential on international trade may affect international trade in service in a different way or even may not be influential on international trade in services. Due to this reason, scholars begun to conduct research focusing on the factors, that may specifically affect international trade in services, in recent years (Zong-biao, 2010; Eichengreen \& Gupta, 2013; Yousefi, 2018, Abasimi, Vorlak, Salim \& Li, 2019).

As known, each country has its own country-specific conditions that affects all actors in their economic and social life. Hence, it is important to understand the factors affecting the service trade in a country-specific manner because understanding how country-specific factors shape the service trade, which constitutes the substantial part of each economy, is important especially for developing countries. Although this is the case, there are not enough effort to comprehend service trade in Turkish literature. So that, to enhance the understanding about Turkish service trade, which is not widely studied, this 
research aims to discover some of variables (informal economy, FDI, globalization, internet technology) that possibly affects Turkish service trade and not widely studied from the perspective of Turkish service trade. Therefore, this research purposes to answer the question do impacts of factors affecting goods trade differentiate for service trade. This research includes significant contributions for the literature. Since this research takes only Turkish service export into account and covers relatively less studied variables, it would provide inclusive and country-specific perspective for Turkey.

To achieve research objective, this research is designed as quantitative research using secondary data produced for Turkey and obtained from various reputable sources. In addition, this research used ARDL model to test research hypotheses. The following parts of the research will be about literature review that describes conceptual framework of the study, research method, and results and conclusion.

\section{LITERATURE REVIEW}

2.1. Understanding the Differences Between International Trade in

\section{Goods and International Trade in Services}

International trade is generally thought as an international trade of only physical products. However, at the beginnings of 2000s, it was begun to be thought that it is possible to exist special form of international trade for services which have different characteristics compared to goods. Therefore, researchers have begun to carry out studies that aim to understand international trade of services and its differences.

To show the differences between them, international trade of goods and international trade of services have been defined separately. The most widely accepted definition is provided by Organization for Economic Cooperation and Development (OECD). While OECD defines international trade in services as "the recording the value of services exchanged between residents and nonresidents of an economy, including services provided through foreign affiliates established abroad", it defines international trade in goods as "all goods which add to, or subtract from, the stock of material resources of a country by entering its economic territory (imports) or leaving it (exports)".

In addition to definitional differences, Lennon (2008) and Ariu (2016) have touched on the differences between these two concepts from the point of different perspectives. While Lennon (2008) takes the attention on differences in terms of impact of language and physical geography on international trade of goods and services, Ariu (2016) underlines the existence of differences in the amount of export and import of firms making international trade of goods and services, or in entry and exit ratios of these companies. Lennon (2008) has found 
out that while the effect of physical geography on trade in services is lower, the impact of language on trade in services is higher compared to trade in goods. In addition to Lennon's (2008) findings, Ariu (2016) has concluded that the export and import amount of service trader is less than goods traders. Also, he has stated that service traders experience higher entry and exit rates and a lower survival probability.

Since international trade in goods and international trade in services have different characteristics, the elements, which affect them and are affected by them, have also been begun to be researched separately. The reason is the thought that same elements can affect both in a different way or there might be factors that affect one of them and does not affect the other. By keeping this thought in mind, this research aims to find answers to questions that do the variables accepted as influential on international trade (generally thought as international trade in goods) affect the international trade in service and if it is, how do they influence international trade in services.

\subsection{International Trade and Informal Economy}

Informal economy is a phenomenon that affects all actors of an economy. Businessdictionary.com simply defines informal economy as "system of trade or economic exchange used outside state controlled or money-based transactions." Informal economy is an influential concept on various areas ranging from employment to trade. In the literature, there are research stating that informal economy impacts international trade in different ways (Sarıkaya, 2007; Doğanlar, Bal and Özmen, 2004; Sinha 2011). From theoretical perspective, Sinha (2011) explains the relationship between informal economy and trade according to three different views: dualistic view, legalistic view, and structuralist view. While dualistic view states that actors only in the formal economy may carry out international trade activities and existence of large informal economy disadvantages international trade, legalistic view emphasizes that informalization is detrimental for trade because of the failure of the government to address trade and economic development (Sinha, 2011). In addition to these views, structuralist view says that informal economy occurs as a response to the obstacles encountered in economic development and limits the economy to absorb gains from trade (Sinha, 2011). In short, all views on the relationship between international trade and informal economy presented by Sinha (2011) state that informal economy is a factor which is detrimental for trade. Sarıkaya (2007), who approaches to the topic from different perspective, has touched upon inaccurate calculation of balance of trade resulted from informal economy and problems occurred due to this reason. In addition to these, by referring Özsoylu (1997), Doğanlar, Bal and Özmen (2004) have stated that informal economy made 
production for domestic demand more attractive and caused export to lose its importance compared to past. Also, Bilgiç (2019a) has proposed that decrease in informal economy may enhance service export in Turkey by examining fluctuations in variables between 1991 and 2015. Furthermore, Elgin and Öztunalı (2014) have exhibited in most regressions that trade openness is positively related with informal economy size. In another study, Elgin and Birinci (2016) have found that there is an inverted-U relationship between informal sector size and growth of GDP per capita which is associated with higher degree of trade openness. Finally, Mawusi (2021) has shown that there is a long run relationship between informality, growth, and openness to trade in Ghana, and as Ghana become more open to trade, the size of the informal economy rises. In the light of three views of Sinha (2011) and studies shared above, the first research hypothesis is constructed as:

H1: There is a negative and significant relationship between Turkish service export and informal economy.

\subsection{International Trade and Foreign Direct Investment}

Foreign Direct Investment (FDI) is one of the most important components of development for any country. OECD defines it as "the category of international investment that reflects the objective of a resident entity in one economy to obtain a lasting interest in an enterprise resident in another economy". Since it is a very crucial concept for countries, conditions, which attract FDI, and factors, which are affected by FDI, can be shown among the topics widely researched in the field of FDI. In this respect, New Trade Theory has brought into the open that FDI may have both a substitution effect and complementarity effect on trade circumstantially (Albulescu and Goyeau, 2016). In this sense, Fontagné (1999) explains the impacts of inward and outward FDI on export and import under four different situations. According to Fontagné (1999), these situations are: 1) Exports are affected by inward FDI in where a foreign firm located in the host country has intention to export back home, or supply products to a regional market, 2) Outward FDI affects exports due to increased competitiveness in foreign markets, 3) Imports are impacted by inward FDI due to increased competitiveness of foreign firms operating in domestic market, however, it is possible to increase the exports if the host country obtains competitiveness, and 4) Imports are influenced by outward FDI if backward vertical integration and/or relocation of labor-intensive activities abroad happens (Fontagné, 1999). In addition to propositions of New Trade Theory, there are studies examining FDI and trade relationship empirically. For example, Zhang (2005) has concluded that FDI plays important role in Chinese export boom, but this does not mean that FDI enhance export automatically because Chinese 
country-specific advantages also have crucial role in export boom. Sun (2009) has stated that FDI affects exports of firms positively, but the impact depends on some variables such as geographical location, ownership structure, etc. Harding and Javorcik (2012) have found out a positive effect of FDI on unit values of exports in developing countries, however, they could not find any indication that FDI increases the similarity of export structure of developing and developed economies. Xiong and Sun (2021) have shown that while FDI flowing from developed countries to developing countries enhances exports, FDI flows among developed countries are less significant in enhancing exports. There is also other research taken the relationship between FDI and international trade in services specifically into account (Zong-biao, 2010; Bilgiç, 2019a; Abasimi, Vorlak, Salim \& Li, 2019). Zong-biao (2010) has studied out that there exists a long-term stable equilibrium relationship among FDI, goods trade exports and service trade exports. Dong and Zhang (2016) have found out that as FDI increases, exports of China's service trade will increase. Ahmad and others (2017) have concluded that FDI is an important determinants of service trade which stimulates service export. Bilgiç (2019a) has proposed that FDI and Turkish service export can be positively related after he examined related literature and fluctuations in both FDI and Turkish service export for the period of 1990-2017. Abasimi and others (2019) have also concluded existence of significant relationship between FDI and service export. By taking into New Trade Theory and studies mentioned above account, the second research hypothesis is as follows:

$\mathrm{H} 2$ : There is a positive and significant relationship between Turkish service export and FDI inflow.

\subsection{International Trade and Globalization}

Globalization is a phenomenon in which its history dates to the end of 1800 s and has worldwide impacts. Although there is no universally accepted definition of globalization, KOF (Swiss Economic Institute), which is a very reputable Swiss institute, defines it as "the process of creating networks of connections among actors at intra- or multi-continental distances, mediated through a variety of flows including people, information and ideas, capital, and goods and as the process that erodes national boundaries, integrates national economies, cultures, technologies and governance, and produces complex relations of mutual interdependence" (Gygli, Haelg, Potrafke \& Sturm, 2018). On the other hand, economic globalization, which is a specific type of globalization, can be defined as the rapid proliferation of cross-border production, trade, and investment activities spearheaded by global corporations and international financial institutions that facilitate the emergence of an increasingly integrated and interdependent global economy (Dicken, 1998 cited 
in Yeung, 2002: 287). From this conceptual framework, it is possible to say that globalization has affected international trade. In this context, the relationship between globalization and international trade has been examined by different scholars (Kim \& Shin, 2002; İncekara \& Savrul, 2011; Adıgüzel, 2013). Kim and Shin (2002) have concluded that increase in globalization between 1959 and 1996 has led the world trade network to become denser. İncekara and Savrul (2011) have proposed that globalization process and participating international institutions enhance trade activities especially in developing countries. Adigüzel (2013) has stated that after 1980, Turkish foreign trade volume increased rapidly due to the acceleration of globalization. Savrul and İncekara (2015) have shown that there is a positive and significant relationship between international trade and globalization. Akpan and Atan (2015) have also concluded that globalization has positive impact on trade. Furthermore, Matore and Sagar (2015) have explained the relationship between globalization and international trade from historical perspective. Bilgiç (2019b) has put forward that globalization may affect service export through moderating effect of informal economy. In consideration of economic globalization conceptualization and studies above, the third research hypothesis is:

H3: There is a positive and significant relationship between Turkish service export and globalization.

\subsection{International Trade and Internet Technology}

Internet is an invention that has changed the fundamentals of almost all fields. The benefits, that the internet has brought such as rapid and worldwide communication, easing in keeping records, easing conducting research etc., have affected the way of living, the way of doing business and the way of carrying trade activities. In this sense, authors have conducted research examining how the developments in internet affected international trade (Freund \& Weinhold, 2004; Clarke \& Wallsten, 2006; Meijers, 2014; Lin, 2015; Şeker, 2017). Freund and Weinhold (2004) have found out that internet stimulates trade, and it is likely due to internet-related reduction in fixed costs. Clarke and Wallsten (2006) have concluded that access to the internet does improve export performance in developing countries, although not in developed countries. Meijers (2014) has exhibited positive impact of the internet use on international trade. Lin (2015) has also reached empirical results showing strong effect of the internet on trade improvement. Şeker (2017) has either obtained similar results and concluded that internet usage has meaningful impact on trade volume between Turkey and European Union countries. There are also some other research specifically focusing on the impact of the internet on international trade in services (Choi, 2010; Yousefi, 2018; Bilgiç, 2019b; Luong \& Ngyuen, 2020). These studies have 
also found out positive relationship between variables. By taking account of studies above, the fourth research hypothesis is:

H4: There is a positive and significant relationship between Turkish service export and internet technology.

Table 1. The Summary of Literature

\begin{tabular}{|c|c|c|c|}
\hline Variables & Source & Analysis & $\begin{array}{c}\text { Analyzed } \\
\text { Country }\end{array}$ \\
\hline \multirow{7}{*}{$\begin{array}{l}\text { International } \\
\text { Trade and } \\
\text { Informal } \\
\text { Economy }\end{array}$} & Sarıkaya (2007: 39) & Theoretical Discussion & - \\
\hline & $\begin{array}{c}\text { Özsoylu (1997) cited in } \\
\text { Doğanlar, Bal and Özmen, } \\
(2004: 93)\end{array}$ & Theoretical Discussion & - \\
\hline & Sinha $(2011: 136)$ & Theoretical Discussion & - \\
\hline & Bilgiç (2019a: 160) & Numerical Analysis & Turkey \\
\hline & $\begin{array}{c}\text { Elgin and Birinci (2016: } \\
\text { 289) }\end{array}$ & Econometric Analysis & 161 Countries \\
\hline & $\begin{array}{c}\text { Elgin \& Öztunalı (2014: } \\
152)\end{array}$ & Econometric Analysis & 141 Countries \\
\hline & Mawusi (2021: 5) & Econometric Analysis & Ghana \\
\hline \multirow{9}{*}{$\begin{array}{l}\text { International } \\
\text { Trade and FDI }\end{array}$} & Zhang (2005: 10) & Econometric Analysis & China \\
\hline & Sun (2009: 1221) & Econometric Analysis & China \\
\hline & $\begin{array}{l}\text { Harding and Javorcik (2012: } \\
\text { 979) }\end{array}$ & Econometric Analysis & 105 Countries \\
\hline & Xiong and Sun (2021: 542) & Econometric Analysis & 140 Countries \\
\hline & Zong-biao (2010: 1) & Econometric Analysis & China \\
\hline & Dong and Zhang (2016: 42) & Econometric Analysis & China \\
\hline & $\begin{array}{c}\text { Ahmad and others (2017: } \\
129)\end{array}$ & Econometric Analysis & 13 Countries \\
\hline & Bilgiç (2019a: 162) & Numerical Analysis & Turkey \\
\hline & $\begin{array}{l}\text { Abasimi and others (2019: } \\
39)\end{array}$ & Econometric Analysis & 10 Countries \\
\hline \multirow{7}{*}{$\begin{array}{l}\text { International } \\
\text { Trade and } \\
\text { Globalization }\end{array}$} & Kim and Shin (2002: 445) & Econometric Analysis & 105 Countries \\
\hline & $\begin{array}{l}\text { İncekara and Savrul (2011: } \\
\text { 19) }\end{array}$ & Numerical Analysis & Turkey \\
\hline & Adıgüzel (2013: 18) & Numerical Analysis & Turkey \\
\hline & Bilgiç (2019a: 158) & Numerical Analysis & Turkey \\
\hline & $\begin{array}{c}\text { Savrul and İncekara (2015: } \\
93)\end{array}$ & Econometric Analysis & 12 Countries \\
\hline & Akpan and Atan (2015: 154) & Econometric Analysis & Nigeria \\
\hline & $\begin{array}{l}\text { Matore and Sagar (2015: } \\
94)\end{array}$ & Numerical Analysis & India \\
\hline \multirow{2}{*}{$\begin{array}{c}\text { International } \\
\text { Trade and }\end{array}$} & $\begin{array}{c}\text { Freund, and Weinhold } \\
(2004: 171)\end{array}$ & Econometric Analysis & 56 Countries \\
\hline & Clarke and Wallsten (2006) & Econometric Analysis & 98 Countries \\
\hline
\end{tabular}

\section{4}


KAUJEASF 12(24), 2021: 1056-1078

\begin{tabular}{|c|c|c|c|}
\hline $\begin{array}{c}\text { Internet } \\
\text { Technology }\end{array}$ & Lin (2015: 424) & Econometric Analysis & $\begin{array}{c}\text { Nearly } 200 \\
\text { Countries }\end{array}$ \\
\cline { 2 - 4 } & Şeker (2017: 86) & Econometric Analysis & 26 Countries \\
\cline { 2 - 4 } & Yousefi (2018: 65) & Econometric Analysis & 63 Countries \\
\cline { 2 - 4 } & Choi (2010: 104) & Econometric Analysis & 151 Countries \\
\cline { 2 - 4 } & Meijers (2014: 161) & Econometric Analysis & 162 Countries \\
\cline { 2 - 4 } & $\begin{array}{c}\text { Luong and Ngyuen (2020: } \\
1073)\end{array}$ & Econometric Analysis & 228 Countries \\
\hline
\end{tabular}

In Table 1, the literature review above is summarized based on analysis and analyzed country. As seen, research focusing on Turkey have used numerical analysis and research focusing on group of countries (possibly including Turkey) have used econometric analysis. Therefore, it is important for the literature to focus only on Turkey by using econometric analysis from the perspective of service export.

\section{RESEARCH METHOD}

\subsection{Data}

Data used in this research are secondary data collected from highly reputable sources for the period of 1970 - 2018. The sources of data are represented in Table 2.

Table 2. Sources of Data Used in the Research

\begin{tabular}{|c|c|c|}
\hline Variables & Period of Data & Used Sources \\
\hline $\begin{array}{l}\text { Turkish Service } \\
\text { Export }\end{array}$ & $1984-2018$ & OECD Database \\
\hline Net FDI Inflow & $1974-2018$ & World Bank Database \\
\hline Internet & $1993-2017$ & $\begin{array}{c}\text { International Telecommunication Union, World } \\
\text { Telecommunication/ICT Development Report } \\
\text { and Database }\end{array}$ \\
\hline Informal Economy & $1971-2016$ & $\begin{array}{c}\text { IMF (International Monetary Fund) Working } \\
\text { Papers; Medina, L., \& Schneider, F. (2018). } \\
\text { Shadow Economies Around the World: What } \\
\text { Did We Learn Over the Last } 20 \text { Years?. } \\
\text { \& } \\
\text { Çetintaş, H., \& Vergil, H. (2003). Türkiye'de } \\
\text { Kayıtdış1 Ekonominin Tahmini. Dogus } \\
\text { Universitesi Dergisi, 4(1), 15-30. }\end{array}$ \\
\hline Globalization & $1970-2016$ & Swiss Economic Institute, KOF Index \\
\hline
\end{tabular}


As known, Organization of Economic Cooperation and Development (OECD), World Bank (WB) and International Monetary Fund (IMF) are highly reputable institutions, and their data are accepted as highly valid. Turkish service export is calculated in millions of American dollars, net foreign direct investment inflow is calculated as percentage in GDP, internet technology is calculated as percentage of people using internet and informal economy is calculated as size of the informal economy in percentage of GDP.

Data about globalization are taken by database of Swiss Economic Institute (KOF). Swiss Economic Institute is a highly reputable international institute which delivers profound insight into the field of economic research. One of the indexes produced by Swiss Economic Institute is KOF Globalization Index. The KOF Globalization Index is an index that measures the economic, social, and political dimensions of globalization. The increase in the value of the index means increase in the level of globalization of the country. In this research, KOF Globalization Index of Turkey is used to measure globalization.

\subsection{ARDL model of the research}

Testing the long-term relationship between variables is usually done by using cointegration analyzes. Although there are different cointegration methods in the literature, ARDL cointegration method has been utilized in this study due to its advantages. These advantages are; applicability without checking whether variables are $\mathrm{I}(0)$ or $\mathrm{I}(1)$, ability to use unrestricted error correction model, applicability for small samples (Pesaran, Shin, \& Smith, 2001; Narayan \& Narayan; 2005; Narayan \& Smyth, 2005; Pamuk \& Bektaş, 2014).

\subsubsection{Specification tests}

Before conducting ARDL analysis, it is required to do unit root tests and CUSUM, CUSUMSQ test, and to check for autocorrelation, normal distribution, and heteroscedasticity. In this sense, firstly, Augmented Dickey Fuller (ADF) test was done, and as seen in Table 3, there is a stability at the first difference for all variables at $\% 5$ critical values. Then, to check autocorrelation and heteroscedasticity, Breusch-Godfrey Serial Correlation LM Test and BreuschPagan-Godfrey Heteroskedasticity Test was done. The results of these tests are provided in Table 4 and it is seen that there is no problem of autocorrelation and heteroscedasticity. Furthermore, data was controlled for normal distribution by using skewness and kurtosis values. In Table 5, descriptive statistics are shared. By using reference points of -2 and +2 for skewness (George, 2011) and reference points of -7 and +7 for kurtosis (Byrne, 2011) as an indicator of normal distribution, it was decided that data are normally distributed. Lastly, CUSUM and CUSUMSQ (Figure 1 and 2) tests was conducted, and it was seen that there 
is a stability. At the end of these analyses, it was shown that ARDL analysis is applicable in the scope of this research.

Table 3. ADF Unit Root Test

\begin{tabular}{|c|c|c|c|c|c|}
\hline \multirow{5}{*}{$\begin{array}{c}\text { Variables } \\
\text { Informal } \\
\text { Economy (I.E) }\end{array}$} & \multirow{5}{*}{$\begin{array}{c}\begin{array}{c}\text { T-Statistic } \\
\text { "Intercept and } \\
\text { trend" }\end{array} \\
-5.635084\end{array}$} & \multicolumn{4}{|c|}{ ADF Unit Root Test } \\
\hline & & \multicolumn{2}{|c|}{ Test Critical Values } & \multirow{4}{*}{$\begin{array}{c}\text { P Values } \\
0.0002\end{array}$} & \multirow{4}{*}{$\begin{array}{c}\text { Decision } \\
\text { Stationary at } \\
\text { all critical } \\
\text { values } \\
\end{array}$} \\
\hline & & $\% 1$ & -4.180911 & & \\
\hline & & $\% 5$ & -3.515523 & & \\
\hline & & $\% 10$ & -3.188259 & & \\
\hline \multirow{3}{*}{ Internet (INT) } & \multirow{3}{*}{-3.801419} & $\% 1$ & $-4,416345$ & \multirow{3}{*}{0.0352} & \multirow{3}{*}{$\begin{array}{l}\text { Stationary at } \\
\% 5 \text { and } \% 10\end{array}$} \\
\hline & & $\% 5$ & -3.622033 & & \\
\hline & & $\% 10$ & -3.248592 & & \\
\hline \multirow{3}{*}{$\begin{array}{l}\text { Globalization } \\
\text { (GLOB) }\end{array}$} & \multirow{3}{*}{-6.698259} & $\% 1$ & -4.175640 & \multirow{3}{*}{0.0000} & \multirow{3}{*}{$\begin{array}{c}\text { Stationary at } \\
\text { all critical } \\
\text { values }\end{array}$} \\
\hline & & $\% 5$ & -3.513075 & & \\
\hline & & $\% 10$ & -3.186854 & & \\
\hline \multirow{3}{*}{ FDI } & \multirow{3}{*}{-5.989186} & $\% 1$ & -4.186481 & \multirow{3}{*}{0.0001} & \multirow{3}{*}{$\begin{array}{l}\text { Stationary at } \\
\text { all critical } \\
\text { values }\end{array}$} \\
\hline & & $\% 5$ & -3.518090 & & \\
\hline & & $\% 10$ & -3.189732 & & \\
\hline \multirow{3}{*}{$\begin{array}{l}\text { Service Export } \\
\text { (S.EXPORT) }\end{array}$} & \multirow{3}{*}{-6.572855} & $\% 1$ & -4.262735 & \multirow{3}{*}{0.0000} & \multirow{3}{*}{$\begin{array}{c}\text { Stationary a } \\
\text { all critical } \\
\text { values }\end{array}$} \\
\hline & & $\% 5$ & -3.552973 & & \\
\hline & & $\% 10$ & -3.209642 & & \\
\hline
\end{tabular}

Table 4. Autocorrelation and Heteroskedasticity Tests

\begin{tabular}{|c|c|c|c|}
\hline \multicolumn{5}{|c|}{ Breusch-Godfrey Serial Correlation LM Test } \\
\hline F-Statistic & 2.073305 & Prob. F $(2,3)$ & 0.2720 \\
\hline \multicolumn{4}{|c|}{ Breusch-Pagan-Godfrey Heteroskedasticity Test } \\
\hline F-Statistic & 0.313773 & Prob. F $(16,5)$ & 0.9652 \\
\hline
\end{tabular}

Table 5. Descriptive Statistics

\begin{tabular}{|c|c|}
\hline Mean & $-5.65 \mathrm{e}-16$ \\
\hline Median & 0.001856 \\
\hline Maximum & 0.026508 \\
\hline Minimum & -0.043175 \\
\hline Standard Deviation & 0.014015 \\
\hline Skewness & -1.089529 \\
\hline Kurtosis & 5.456062 \\
\hline
\end{tabular}




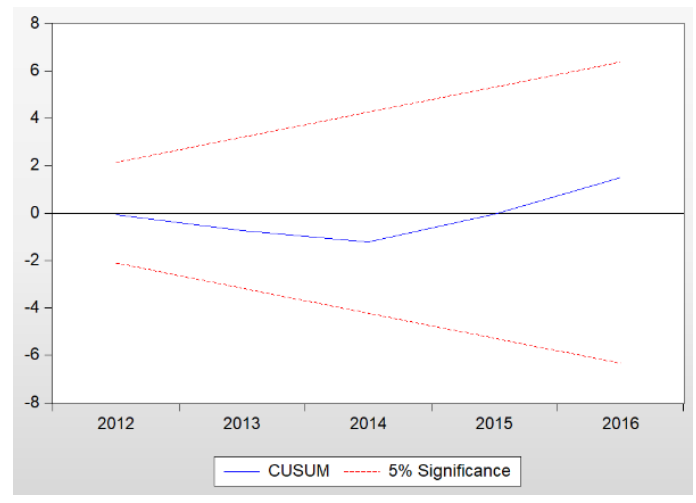

Figure 1: CUSUM Test

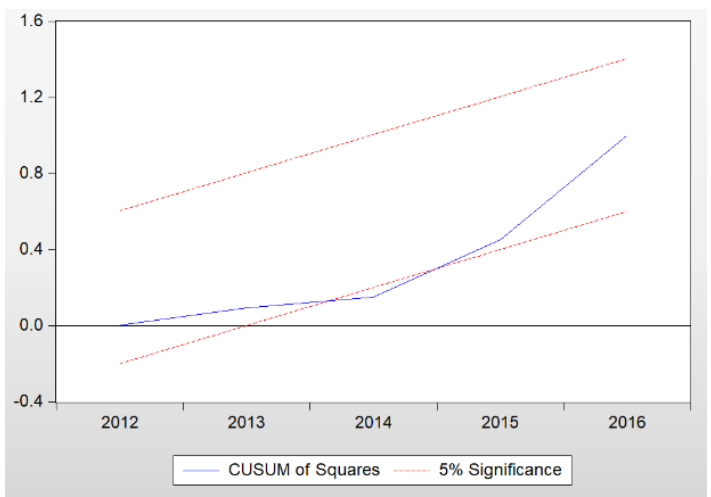

Figure 2: CUSUMSQ Test

\subsubsection{ARDL model}

Autoregressive Distributed Lag Bound Models (ARDL) are standard least squares regression which is making estimation over the lagged values of both dependent and independent variables. The basic $\operatorname{ARDL}(p, q)$ regression model can be defined as follows:

$$
Y_{t}=\beta_{0}+\beta_{1} Y_{t-1}+\cdots+\beta_{k} Y_{t-p}+\alpha_{0} X_{t}+\alpha_{1} X_{t-1}+\cdots+\alpha_{q} X_{t-q}+\varepsilon_{t}
$$

Here, $\varepsilon_{t}$ is the error term.

The cointegration relationship of the variables is primarily determined according to the ARDL boundary test approach, which was developed by 
Pesaran, Shin and Smith (2001). For this purpose, unrestricted error correction model in Formula 2 is defined. In this research, $(3,3,1,2,3)$ model was selected.

$$
\begin{aligned}
& \Delta \mathrm{S} . \text { EXPORT }_{\mathrm{t}}=\alpha_{0}+\sum_{\mathrm{i}=1}^{\mathrm{q}} \mathrm{a}_{1 \mathrm{i}} \Delta \mathrm{S} . \mathrm{EXPORT}_{\mathrm{t}-\mathrm{i}}+\sum_{\mathrm{i}=1}^{\mathrm{p}} \mathrm{a}_{2 \mathrm{i}} \Delta \text { GLOB }_{\mathrm{t}-1}+ \\
& \sum_{\mathrm{i}=1}^{\mathrm{p}} \mathrm{a}_{3 \mathrm{i}} \Delta \mathrm{INT}_{\cdot \mathrm{t}-1}+\sum_{\mathrm{i}=1}^{\mathrm{p}} \mathrm{a}_{4 \mathrm{i}} \Delta \mathrm{FDI}_{\mathrm{t}-1}+ \\
& \sum_{\mathrm{i}=1}^{\mathrm{p}} \mathrm{a}_{5 \mathrm{i}} \Delta \mathrm{I} \text {. E.t-1 } \beta_{1} \text { S. EXPORT }_{\mathrm{t}-1}+\beta_{2} \mathrm{GLOB}_{\mathrm{t}-1}+\beta_{3} \mathrm{INT}_{\mathrm{t}-1}+ \\
& \beta_{4} \mathrm{FDI}_{\mathrm{t}-1}+\beta_{5} \mathrm{I} . \mathrm{E}_{\mathrm{t}-1}+\mathrm{u}_{\mathrm{t}}
\end{aligned}
$$

Here, the equation given in (2) consists of model established according to the hypotheses formed above. The meanings of abbreviations are as follows:

- S.EXPORT $=>$ Turkish Service Export

- GLOB $\Rightarrow$ Globalization

- $\quad \mathrm{INT}=>$ Internet Technology

- $\mathrm{FDI}=>$ Foreign Direct Investment Net Inflow

- $\quad$ I.E $=>$ Informal Economy

This system of equation, which is defined as an unrestricted error correction model, is used to test the cointegration relationship.

The null hypothesis formed as "no cointegration in long-term" is defined as:

$$
\mathrm{H}_{0}: \beta_{1}=\beta_{2}=0
$$

When deciding between null and alternative hypotheses, Wald test is applied to model coefficients. The obtained $\mathrm{F}$ statistic values are compared with the lower and upper critical values given in Pesaran's et al. (2001) study. If the F statistic value is above the upper value, it means that there is a cointegration relationship between the variables. If the $\mathrm{F}$ statistic value is less than the lower value, it is stated that there is no cointegration relationship and if it is among the critical values, no interpretation can be made. In the scope of this research, F statistic was calculated as 29.54935 and I0 and I1 bound values are represented in Table 6 below. Since F statistic value of 29.54935 is higher than critical bounds value in Table 6 , it can be stated that that there is a cointegration relationship between the variables. 
Table 6. Critical Value Bounds

\begin{tabular}{|c|c|c|}
\hline Significance & I0 Bound & I1 Bound \\
\hline $10 \%$ & 2.45 & 3.52 \\
\hline $5 \%$ & 2.86 & 4.01 \\
\hline $2.5 \%$ & 3.25 & 4.49 \\
\hline $1 \%$ & 3.74 & 5.06 \\
\hline
\end{tabular}

After determination of the long-term cointegration relationship, the long and short-term coefficients are estimated from the ARDL model given in equation (1). The long-term model is defined as:

$$
\begin{gathered}
\text { S. EXPORT } \mathrm{E}_{\mathrm{t}}=\alpha_{0}^{*}+\sum_{\mathrm{i}=1}^{\mathrm{q}} \alpha_{1 \mathrm{i}}^{*} \mathrm{~S}_{\text {EXPORT }} \text { EX }_{\mathrm{i}}+\sum_{\mathrm{i}=1}^{\mathrm{p}} \alpha_{2 \mathrm{i}}^{*} \mathrm{GLOB}_{\mathrm{t}-\mathrm{i}}+ \\
\sum_{\mathrm{i}=1}^{\mathrm{p}} \alpha_{3 \mathrm{i}}^{*} \mathrm{INT}_{\mathrm{t}-\mathrm{i}}+\sum_{\mathrm{i}=1}^{\mathrm{p}} \alpha_{4 \mathrm{i}}^{*} \mathrm{FDI}_{\mathrm{t}-\mathrm{i}}+\sum_{\mathrm{i}=1}^{\mathrm{p}} \alpha_{5 \mathrm{i}}^{*} \mathrm{I}_{\mathrm{t}-\mathrm{i}}+\mathrm{u}_{\mathrm{t}}^{*}
\end{gathered}
$$

The equation given here in (4) consists of model established according to the hypotheses formed above. The * sign above the coefficients represents the long-term coefficients calculated from the ARDL model.

The existence of cointegration relationship between the variables indicates the existence of short-term error correction mechanism. The short-term error correction model is defined as:

$$
\begin{aligned}
& \Delta \text { S. EXPORT } \mathrm{E}_{\mathrm{t}}=\mathrm{a}_{0}+\sum_{\mathrm{i}=1}^{\mathrm{q}} \mathrm{a}_{1 \mathrm{i}} \Delta \mathrm{S} \text { EXPORT }_{\mathrm{t}-1}+\sum_{\mathrm{i}=1}^{\mathrm{p}} \mathrm{a}_{2 \mathrm{i}} \Delta \text { GLOB }_{\mathrm{t}-1}+ \\
& \sum_{\mathrm{i}=1}^{\mathrm{p}} \mathrm{a}_{3 \mathrm{i}} \Delta \mathrm{INT}_{\mathrm{t}-1}+\sum_{\mathrm{i}=1}^{\mathrm{p}} \mathrm{a}_{4 \mathrm{i}} \Delta \mathrm{FDI}_{\mathrm{t}-1}+\sum_{\mathrm{i}=1}^{\mathrm{p}} \mathrm{a}_{5 \mathrm{i}} \Delta \mathrm{I} \cdot \mathrm{E}_{\mathrm{t}-1}+\mathrm{a}_{6} \mathrm{ECM}_{\mathrm{t}-1}+\mathrm{u}_{\mathrm{t}}
\end{aligned}
$$

The equation given here in (5) consists of models established according to the hypotheses formed above. In the model, $\alpha_{6}$ is called as error correction coefficient. The term of error correction refers to long-term equilibrium rate that occurs in short-term after a shock. The term of negative and statistically significant error correction indicates the existence of a convergence towards the long-term equilibrium point.

\section{RESULTS}

To analyze the relationships mentioned in the research hypotheses, cointegration analysis was conducted by using ARDL Model described above. The results obtained from ARDL model for long-term period and short-term period are represented in Table 9 and Table 10 respectively, and ARDL results and regression statistics of the model are shown in Table 7 and Table 8 respectively. While the coefficients given in second column of the tables shows the direction of relationship between stated variable in the first column and the dependent variable, which is Turkish service export, the p-value given in the last column of the tables shows whether the relationship between the variable in the 
first column of the tables and Turkish service export is significant or nonsignificant. If the p-value is below the 0,05 , it can be stated that the relationship between the variable in the first column and Turkish service export is significant. Otherwise, it cannot be stated that the relationships between the variables are significant. By considering Table 7 and 8 , when Table 9 and 10 are examined, it is seen that hypotheses except third hypothesis are approved both in short-term and long-term period.

Table 7. ARDL Results

\begin{tabular}{|c|c|c|c|c|}
\hline Variables & Coefficient & Std. Error & t-statistic & p-value \\
\hline LOG (S.EXPORT (-1)) & -0.192048 & 0.119047 & -1.613206 & 0.1676 \\
\hline LOG (S.EXPORT (-2)) & -0.398877 & 0.114606 & -3.480404 & 0.0177 \\
\hline LOG (S.EXPORT (-3)) & 0.755245 & 0.103013 & 7.331576 & 0.0007 \\
\hline LOG (I.E) & -0.251558 & 0.049253 & -5.107441 & 0.0037 \\
\hline LOG (I.E(-1)) & -0.508791 & 0.087463 & -5.817244 & 0.0021 \\
\hline LOG (I.E(-2)) & 0.079904 & 0.068698 & 1.163126 & 0.2973 \\
\hline LOG (I.E(-3)) & -0.238862 & 0.089233 & -2.676847 & 0.0440 \\
\hline LOG (GLOB) & -1.636890 & 0.869353 & -1.882883 & 0.1184 \\
\hline LOG (GLOB(-1)) & 0.731917 & 0.962498 & 0.760435 & 0.4813 \\
\hline LOG (INT) & 0.655683 & 0.074337 & 8.820441 & 0.0003 \\
\hline LOG (INT (-1)) & -0.318891 & 0.080781 & -3.947622 & 0.0109 \\
\hline LOG (INT (-2)) & -0.108412 & 0.053529 & -2.025292 & 0.0987 \\
\hline LOG (FDI) & 0.174192 & 0.042179 & 4.129833 & 0.0091 \\
\hline LOG (FDI (-1)) & 0.099225 & 0.040080 & 2.475648 & 0.0561 \\
\hline LOG (FDI (-2)) & -0.125671 & 0.024838 & -5.059667 & 0.0039 \\
\hline LOG (FDI (-3)) & 0.117753 & 0.026686 & 4.412576 & 0.0069 \\
\hline Constant & 8.990355 & 6.203023 & 1.449351 & 0.2069 \\
\hline
\end{tabular}

Table 8. Regression Statistics of the Model

\begin{tabular}{|c|c|c|c|}
\hline R-Squared & 0.999163 & Mean Dependent Var. & 3.152510 \\
\hline Adjusted R-Squared & 0.996487 & S. D. Dependent Var. & 0.484553 \\
\hline S.E. of Regression & 0.028722 & Akaike Info. Criterion & -4.198491 \\
\hline Sum Squared Resid & 0.004125 & Schwarz Criterion & -3.355412 \\
\hline Log Likelihood & 63.18340 & Hanna-Quin Criterion & -3.999887 \\
\hline F-Statistic & 373.2536 & Durbin-Watson Statistic. & 2.993697 \\
\hline Prob. (F-Statistic) & 0.000001 & & \\
\hline
\end{tabular}


Table 9. Long-Term Results

\begin{tabular}{|c|c|c|c|c|}
\hline Variables & Coefficient & Std. Error & t-statistic & p-value \\
\hline LOG (I.E) & -1.100072 & 0.186946 & $-5,884447$ & 0.0020 \\
\hline LOG (GLOB.) & -1.082918 & 1.709938 & -0.633308 & 0.5544 \\
\hline LOG (INT) & 0.273286 & 0.024926 & 10.964003 & 0.0001 \\
\hline LOG (FDI) & 0.317705 & 0.094152 & 3.374400 & 0.0198 \\
\hline Constant & 10.758140 & 7.633648 & 1.409305 & 0.2178 \\
\hline
\end{tabular}

Table 10. Short-Term Results

\begin{tabular}{|c|c|c|c|c|}
\hline Variables & Coefficient & Std. Error & t-statistic & p-value \\
\hline $\begin{array}{l}\text { DLOG (S.EXPORT (- } \\
\text { 1)) }\end{array}$ & -0.356368 & 0.099738 & -3.573028 & 0.0160 \\
\hline $\begin{array}{l}\text { DLOG (S.EXPORT (- } \\
2))\end{array}$ & -0.755245 & 0.103013 & -7.331576 & 0.0007 \\
\hline DLOG (I.E) & -0.251558 & 0.049253 & -5.107441 & 0.0037 \\
\hline DLOG (I.E (-1)) & -0.079904 & 0.068698 & -1.163126 & 0.2973 \\
\hline DLOG (I.E (-2)) & 0.238862 & 0.089233 & 2.676847 & 0.0440 \\
\hline DLOG (GLOB) & -1.636890 & 0.869353 & -1.882883 & 0.1184 \\
\hline DLOG (INT) & 0.655683 & 0.074337 & 8.820441 & 0.0003 \\
\hline DLOG (INT (-1)) & 0.108412 & 0.053529 & 2.025292 & 0.0987 \\
\hline DLOG (FDI) & 0.174192 & 0.042179 & 4.129833 & 0.0091 \\
\hline DLOG (FDI (-1)) & 0.125671 & 0.024838 & 5.059667 & 0.0039 \\
\hline DLOG (FDI (-2)) & -0.117753 & 0.026686 & -4.412576 & 0.0069 \\
\hline CointEq & -0.835679 & 0.131701 & -6.345288 & 0.0014 \\
\hline
\end{tabular}

According to the results in the tables, acceptance/rejection situation of the research hypotheses is provided in Table 11.

Table 11. Acceptance / Rejection Situation of Hypotheses

$$
\text { Hypotheses }
$$

\section{Test Result}

H1: There is a negative and significant relationship between Turkish service export and informal economy.

Accepted

$\mathrm{H} 2$ : There is a positive and significant relationship between Turkish service export and internet technology.

Accepted

H3: There is a positive and significant relationship between Turkish service export and globalization.

Rejected

H4: There is a positive and significant relationship between Turkish

service export and FDI inflow.

Accepted

First, second and fourth hypotheses of this research are accepted because the p-values of each variable related with the hypotheses are below the 0,05 and the direction of the relationships between stated variables are coherent with the 
relationship direction mentioned in the first, second and fourth research hypotheses. However, since the p-value of the variable related with third hypothesis is above the value of 0,05 and the found direction of the relationship is not coherent with the direction of the relationship mentioned in third hypothesis, the third hypothesis is rejected.

\section{DISCUSSION AND CONCLUSION}

According to results, it can be stated that as informal economy in Turkey decreases, number of services that Turkey export increases in both short-term and long-term period. This result might be explained by movement of firms from informal economy to formal economy, recovery in economy and competition, increase in ability to conduct international trade activities.

Since decrease in informal economy is expected to increase Turkish service export, policy makers in Turkey should create policies that can decrease informal economy to enhance service export. In this sense, it can be advised governments to decrease tax rates, to provide incentives to participate in formal economy such as providing credits at desirable interest rates, and to increase awareness of both firms and people about disadvantages of informal economy.

Furthermore, the results have shown that as foreign investors make their investments in Turkey, Turkish service export raises. This result can be clarified by increase in the numbers of firms producing service in domestic market and improvement in international networks of domestic firms.

It is obvious from this result that Turkish government should create policies that attract FDI to enhance Turkish service export. In this sense, Turkish government may provide incentives such as providing land for firms, reduction in tax rates, less bureaucracy, upgrading infrastructure of internet, electricity, transportation, etc., solving the terrorism problem or at least, minimizing the effect of terrorist attacks.

In contrast to hypothesis 3 , the results have concluded that globalization is not influential on Turkish service export significantly. On the top of that, the results have also found out negative relationship between the variables.

Although this result must be researched deeply, the possible reasons of the existence of negative relationship might be as follows:

- The competition power of Turkish service exporter in global market might be inadequate. If this is the case, it is logical that as Turkey become more globalized, Turkish service exporting firms will leave from the market. So that, Turkish service export will decrease (see, Bashimov, 2017).

- The global reputation of Turkey might be getting poorer each day. Turkey may be engaging in activities that harm its global reputation. As 
Turkey and the World globalize more, people living in different country may not be willing to consume Turkish services because of increasing poor global reputation of Turkey (see, Dimitrova, Korschun \& Yotov, 2017). as follows:

The possible reasons of existence of non-significant relationship might be

- Although globalization does not affect Turkish service export, there might be mediating and moderating variables. The globalization might be exhibiting its impact on Turkish service export through mediating and moderating variables (see, Bilgiç, 2019b).

- As is known, while some types of services are not appropriate for international trade because of its nature, some of them are appropriate for international trade. For example, some administrative services provided by governments cannot be traded. So that, if a major part of services is untradeable, the globalization cannot be expected to impact Turkish service export significantly (see, Filipović, Nikolić, \& Katić, 2015).

- Another reason might be that globalization might be impactful on service trade when it reaches certain threshold. From this point of view, the last globalization score of Turkey $(\% 64,03)$ might be below the threshold value that we assume that it exists. So that, globalization's impact may not had appeared on Turkish service export yet.

These reasons ordered above to explain why globalization is not impactful on Turkish service export are only assumptions. These assumptions and other possible reasons that is not mentioned should be researched.

Lastly, it was found out that as internet technology spreads around Turkey, Turkish service export will improve. It is possible to explain this result with the advantages of internet for service trade such as eased communication and increase in ability to reach international customers, and creation of new service fields.

According to data of World Bank for 2018, approximately \% 70 of people is using internet in Turkey. Compared to countries exporting service in amounts above the world average such as United Kingdom (\%94), France (\%82), Japan $(\% 85)$ and United States (\%87), the rate of individuals using internet in Tukey is low. In this sense, Turkey must upgrade internet infrastructure around the country (not only in west regions of the country but also in east regions of the country). Also, Turkish government should encourage activities towards development of new software and applications that enhance service export via internet. For example, enterprises, which are like amazon.com, aliexpress.com or are completely innovative and service based, should be supported. In addition, companies producing services and university students should be trained about online services. Through these ways, Turkish service export might be improved. 
In sum, this research has investigated the impact of informal economy, internet technology, globalization and FDI on Turkish service export by using ARDL model. Depending on results, possible reasons which might have led to these results have been explained and recommendations for policy makers have provided. This research may also open the doors of new studies. In this sense, it might be advised for future studies to examine countries from different development levels in the scope of service trade. It may also be beneficial to use projection techniques specially to investigate threshold level of globalization if exist. Since there is no perfect study, this research has some limitations including lack of comparison among countries, using only one method, having limited amount of data for some data between 1970 - 2018, and non-inclusion of other critical variables such as exchange rate, GDP, etc.

\section{CONFLICT OF INTEREST STATEMENT}

There is no conflict of interest between the authors. (Single Author)

\section{FUNDING ACKNOWLEDGEMENTS}

This research did not receive any specific grant from any funding agency.

\section{AUTHORS CONTRIBUTION}

EB: Idea;

EB: Design;

EB: Control;

EB: Resources collection and/or processing;

EB: Analysis and/or interpretations;

EB: Literature review;

EB: Writing;

EB: Critical examination

9. ETHICS COMMITTEE STATEMENT AND INTELLECTUAL PROPERTY COPYRIGHTS

Since this research uses secondary data, there were no need for ethics committee permission. Intellectual property and copyright principles have been taken care at most level in the article.

\section{REFERENCES}

Abasimi, I., Vorlak, L., Salim, A., \& Li, X. (2019). Determinants of export service in selected west African countries. International Journal of Applied Economics, Finance and Accounting, 5(2), 39-47.

Adıgüzel, M. (2013). Ekonomik küreselleşmenin Türkiye ekonomisine etkileri. Akademik Bakış Dergisi, (35), 1-20.

Ahmad, S. A., Kaliappan, S. R. \& Ismail, N. W. (2017). Determinants of service export in selected developing Asian countries. International Journal of Business and Society, 18 (1), 113-132. 
Akpan, U. F., \& Atan, J. A. (2015). The effect of globalization on selected sectors of the Nigerian economy: agriculture, manufacturing and international trade. Journal of Economics, Management and Trade, 8(2) 144-156.

Albulescu, C. T., \& Goyeau, D. (2016). The interaction between trade and FDI: the CEE countries experience. arXiv preprint arXiv:1609.02334.

Ariu, A. (2016). Services versus goods trade: a firm-level comparison. Review of World Economics, 152(1), 19-41.

Bashimov, G. (2017). Türk tekstil ve hazır giyim sektörünün uluslararası rekabet gücü: ASEAN-5 ülkeleri ile karşılaştırmalı analiz. Adnan Menderes Üniversitesi Sosyal Bilimler Enstitüsü Dergisi, 4(2), 1-15.

Bilgiç, E. (2019a), Küreselleşme sürecinde kayıt dışı ekonominin Türk hizmet ihracatı üzerindeki etkisi üzerine model önerisi ve tartışma, ARHUSS, (2019), 2(2):144167

Bilgiç, E. (2019b). İnternet teknolojisinin Türk hizmet ihracatı üzerindeki etkisi. Başkent Üniversitesi Ticari Bilimler Fakültesi Dergisi, 3 (1), 22-36.

Byrne, B. M. (2011). Structural equation modeling with Mplus: Basic concepts, applications, and programming. Routledge Press, London.

Çetintaş, H., \& Vergil, H. (2003). Türkiye'de Kayıtdışı Ekonominin Tahmini. Dogus Universitesi Dergisi, 4(1), 15-30.

Choi, C. (2010). The effect of the Internet on service trade. Economics Letters, 109(2), 102-104.

Clarke, G. R. \& Wallsten, S. J. (2006). Has the internet increased trade? Developed and developing country evidence. Economic Inquiry, 44(3), 465-484.

Dimitrova, B. V., Korschun, D., \& Yotov, Y. V. (2017). When and how country reputation stimulates export volume. International Marketing Review, 34(3), 377-402.

Doğanlar, M., Bal, H., \& Özmen, M. (2004). Uluslararası ticaret ve Türkiye'nin ihracat fonksiyonu. Manas Sosyal Bilimler Dergisi, 7, 83-109.

Dong, D. X., \& Zhang, Q. (2016). Empirical analysis on international competitiveness of China's service trade on the basis of diamond model. In 2nd International Conference on Economy, Management, Law and Education (EMLE) (pp. 3943).

Eichengreen, B. \& Gupta, P. (2013). The real exchange rate and export growth: are services different?. The World Bank.

Elgin, C., \& Birinci, S. (2016). Growth and informality: A comprehensive panel data analysis. Journal of applied economics, 19(2), 271-292.

Elgin, C., \& Oztunali, O. (2014). Institutions, informal economy, and economic development. Emerging Markets Finance and Trade, 50(4), 145-162.

Filipović, M., Nikolić, M., \& Katić, G. (2015). Shortage of domestic savings and investments as a barrier to economic development. Industrija, 43(1), 111-132.

Freund, C. L., \& Weinhold, D. (2004). The effect of the Internet on international trade. Journal of international economics, 62(1), 171-189. 
George, D. (2011). SPSS for windows step by step: A simple study guide and reference, 17.0 update, 10/e. Pearson Education India.

Gygli, S., Haelg, F., Potrafke, N., \& Sturm, J. E. (2018). The KOF globalisation indexrevisited. The Review of International Organizations, 1-32.

Harding, T., \& Javorcik, B. S. (2012). Foreign direct investment and export upgrading. Review of Economics and Statistics, 94(4), 964-980.

İncekara, A., \& Savrul, A. G. M. (2011). Küreselleşme, büyüme ve ekonomik entegrasyonlar: Türkiye açısından bir değerlendirme. İstanbul Üniversitesi İktisat Fakültesi Mecmuası, 61(2), 3-22.

informal economy. BusinessDictionary.com. Retrieved August 31, 2019, from BusinessDictionary.com website: http://www.businessdictionary.com/definition/informal-economy.html

Kim, S., \& Shin, E. H. (2002). A longitudinal analysis of globalization and regionalization in international trade: A social network approach. Social Forces, 81(2), 445-468.

Lennon, C. (2008). Trade in services and trade in goods: Differences and complementarities. Paris-Jourdan Science Economiques. Working paper 200852

Lin, F. (2015). Estimating the effect of the internet on international trade. The Journal of International Trade \& Economic Development, 24(3), 409-428.

Luong, T. A., \& Nguyen, T. H. (2020). The impact of ICT on service trade. The Singapore Economic Review, 66(04), 1073-1086.

Matore, A. D., \& Sagar, S. (2015). India's international trade since globalization. The Business \& Management Review, 5(4), 89-94.

Mawusi, C. K. (2021). Does Informality and Trade Openness Impact Long Run Growth? Empirical Evidence from Ghana. Economics Bulletin, 41 (1), 28-40.

Meijers, H. (2014). Does the internet generate economic growth, international trade, or both?. International Economics and Economic Policy, 11(1), 137-163.

Narayan, P. K. \& R. Smyth. (2005). Trade Liberalization and Economic Growth in Fiji. An Empirical Assessment Using the ARDL Approach. Journal of The Asia Pacific Economy, 10(1), 96-115.

Narayan, P. K. \& S. Narayan. (2005). Estimating Income and Price Elasticities of Imports For Fiji in a Cointegration Framework. Economic Modelling, 22, 423-438.

OECD (2019), Trade in goods (indicator). doi: 10.1787/1 ea6b5ed-en (Accessed on 26 August 2019)

OECD (2019), Trade in services (indicator). doi: 10.1787/3796b5f0-en (Accessed on 26 August 2019)

Pamuk, M., \& Bektaş, H. (2014). Türkiye'de eğitim harcamaları ve ekonomik büyüme arasındaki ilişki: ARDL sınır testi yaklaşımı. Siyaset, Ekonomi ve Yönetim Araştırmaları Dergisi, 2(2), 77-90.

Pesaran, M. H., Shin, Y., \& Smith, R. J. (2001). Bounds testing approaches to the analysis of level relationships. Journal of Applied Econometrics, 16(3), 289-326.

Pesaran, M. H., Shin, Y., \& Smith, R. J. (2001). Bounds testing approaches to the analysis of level relationships. Journal of applied econometrics, 16(3), 289-326. 
Sarıkaya, H. E. (2007). Kayıt dışı ekonominin ekonomik büyümeye etkisi: Türkiye örneği (1980-2005). Doctoral dissertation, Selçuk Üniversitesi, Sosyal Bilimler Enstitüsü.

Savrul, M., \& Insecara, A. (2015). The effect of globalization on international trade: The black sea economic cooperation case. In International Conference on Eurasian (pp. 88-94).

Seker, A. (2017). Uluslararasi Ticarette Internet Kullaniminin Rolü: Türkiye Örnegi. Ege Akademik Bakis, 17(1), 75.

Sinha, A. (2011). Trade and the informal economy. Trade and Employment, 125.

Sun, S. (2009). How does FDI affect domestic firms' exports? Industrial evidence. World Trade, 11, 011.

Xiong, T., \& Sun, H. (2021). Structure and dynamics of global capital and international trade: Analysis of the relationship between exports and foreign direct investment (FDI) from 2001 to 2006. International Journal of Finance \& Economics, 26(1), 542-559.

Yeung, H. W. C. (2002). The limits to globalization theory: a geographic perspective on global economic change. Economic geography, 78(3), 285-305.

Yousefi, A. (2018). Estimating the effect of the internet on international trade in services. Journal of Business Theory and Practice, 6(1), 65.

Zhang, K. H. (2005, June). How does FDI affect a host country's export performance? The case of China. In International conference of WTO, China and the Asian Economies (pp. 25-26).

Zong-biao, W. S. L. H. (2010). Service FDI inflow and service trade exports of host country: An empirical study based on Chinese data. Journal of International Trade, 11, 011. 